\title{
Crop water use and stage-specific crop coefficients for irrigated cotton in the mid- south, United States
}

\section{Authors: Vipan Kumar, Theophilus K. Udeigwe, Ernest L. Clawson, Robert V. Rohli, \& Donnie K. Miller}

This is a postprint of an article that originally appeared in Agricultural Water Management in July 2015.

Kumar, Vipan, Theophilus K. Udeigwe, Ernest L. Clawson, Robert V. Rohli, and Donnie K. Miller. "Crop water use and stage-specific crop coefficients for irrigated cotton in the mid-south, United States." Agricultural Water Management 156 (July 2015): 63-69.

DOI: https://dx.doi.org/10.1016/j.agwat.2015.03.022

Made available through Montana State University's $\underline{\text { ScholarWorks }}$

scholarworks.montana.edu 


\title{
Crop water use and stage-specific crop coefficients for irrigated cotton in the mid-south, United States
}

\author{
Vipan Kumar $^{\mathrm{a}, 1}$, Theophilus K. Udeigwe ${ }^{\mathrm{b}, *, 1}$, Ernest L. Clawson ${ }^{\mathrm{c}, 1}$, Robert V. Rohli ${ }^{\mathrm{d}}$, \\ Donnie K. Miller ${ }^{\mathrm{e}}$ \\ a Department of Plant Sciences and Plant Pathology, Montana State University, 119 Plant Bioscience Building, Bozeman, MT 59717-3150, USA \\ ${ }^{b}$ Department of Plant and Soil Science, Texas Tech University, Lubbock, TX 79409, USA \\ ' Monsanto Company, 800 North Lindbergh Boulevard, St. Louis, MO 63167, USA \\ d Department of Geography and Anthropology, Louisiana State University, Baton Rouge, LA 70803, USA \\ e LSU AgCenter Northeast Research Station, Saint Joseph, LA 71366, USA
}

\begin{abstract}
:
Regional variations in environmental conditions, cultivars, and management practices necessitate locally derived tools for crop water use estimation and irrigation scheduling. A study was conducted in northeast Louisiana (mid-south US) aimed at estimating daily crop evapotranspiration $\left(E T_{C}\right)$ and reference evapo-transpiration $\left(E T_{0}\right)$ and thus, developing local crop coefficient $\left(\mathrm{K}_{\mathrm{C}}\right)$ curves for irrigated upland cotton. $\mathrm{ET}_{\mathrm{C}}$ was determined using paired weighing lysimeters installed near the middle of a 1-ha cotton field and planted with cotton as in the rest of the surrounding field, while ETo was calculated using the Standard-ized Reference Evapotranspiration Equation (SREE) developed by the American Society of Civil Engineers (ASCE), using estimates of weather variables from a nearby standard reference weather station. Stage-specific $\mathrm{K}_{\mathrm{C}}$ values averaged over 2 years were $0.42,1.25$ and 0.70 for initial, midseason, and end season stages of cotton, respectively. The initial-stage $\mathrm{K}_{\mathrm{c}}$ value was approximately $26 \%$ lower than the Food and Agricultural Organization (FAO)-adjusted initial $\mathrm{K}_{\mathrm{C}}$ value. The mid- and end-season $\mathrm{K}_{\mathrm{C}}$ values obtained in the study were approximately $6 \%$ and $11 \%$ greater, respectively, than the $\mathrm{FAO}$-adjusted $\mathrm{K}_{\mathrm{C}}$ values for the corresponding stages. The observed differences among the local stage-specific $K_{C}$ values (especially at initial growth stage of cotton) and the FAO-adjusted initial $\mathrm{K}_{\mathrm{C}}$ values could be attributed to regional vari-ations in environmental conditions, cultivars, and management practices. The $E T_{C}$ and $K_{C}$ values obtained from this study provide research-based information for future studies and the development of $\mathrm{K}_{\mathrm{C}}$-based irrigation tools in this region.
\end{abstract}

\section{Introduction}

Cotton (Gossypium hirsutum L.) is an important commercial crop grown in the mid-south US, including states such as Missouri, Arkansas, Tennessee, Mississippi, and Louisiana (Vories et al., 2007). In 2012, Louisiana was ranked 11th nationwide among cotton-producing states with a majority of its cotton acreage located in the northeastern part of the state (USDA-NASS, 2013). Recently, the significance of irrigation in attaining and sustaining optimum productivity of major crops in this region has been documented. Vories et al. (2007) reported an increase in irrigated agriculture from 3\% in 1975 to $58 \%$ in 2005 for three mid-south states including Arkansas, Louisiana, and Mississippi. The increasing need and dependence on irrigation, however, is being challenged by the limited knowledge of crop water use in this region as well as excessive groundwater declines in some regions. Due to limited availability of local data on crop water use, researchbased information on proper irrigation scheduling to improve crop productivity and water resource management is lacking in the region.

Building a dependable irrigation scheduling tool requires information on crop evapotranspiration $\left(\mathrm{ET}_{\mathrm{C}}\right)$, which represents the combined processes of water loss through evaporation from soil surface and transpiration from crop surface (Allen et al., 1998). The crop coefficient $\left(\mathrm{K}_{\mathrm{C}}\right)$ methodology of $\mathrm{ET}_{\mathrm{C}}$ estimation was introduced by Jensen (1968) and was further improved by various researchers 
subsequently (Doorenbos and Pruitt, 1977; Allen et al., 1998). In this approach, a single crop coefficient $\left(K_{\mathrm{c}}\right)$ algorithm is developed for a crop experimentally, which can be multiplied by reference evapotranspiration $\left(\mathrm{ET}_{0}\right)$ computed from local microclimatological data to estimate $\mathrm{ET}_{\mathrm{c}}$. This method of $\mathrm{ET}_{\mathrm{c}}$ estimation is widely accepted among researchers and consultants and is considered an inexpensive and practical tool for irrigation scheduling (Allen et al., 1998, 2005; Allen and Pereira, 2009; Ko et al., 2009).

The Food and Agricultural Organization (FAO) of the United Nations has provided details on the development and use of $K_{\mathrm{c}}$ values for different crops in different parts of the world (Allen et al., 1998; hereafter referred to as FAO-56). However, site-specific $K_{\mathrm{c}}$ values determined experimentally for different growth stages of cotton have been considerably different from those listed in the FAO-56 paper (Hunsaker, 1999; Grismer, 2002; Farahani et al., 2008; Bezerra et al., 2012). Thus, the use of generalized $K_{\mathrm{c}}$ values listed in FAO-56 has reportedly resulted in considerable differences between estimated $\mathrm{ET}_{\mathrm{c}}$ and actual $\mathrm{ET}_{\mathrm{c}}$ (Hunsaker et al., 2003; Farahani et al., 2008). Therefore, the development of local-based $K_{\mathrm{c}}$ curves for a more precise crop $\mathrm{ET}_{\mathrm{c}}$ estimation is vital.

Due to limited research-based information on cotton water use in the mid-south US, a research project addressing this topic was initiated in northeastern Louisiana. This study employed the use of paired weighing lysimeters to estimate $\mathrm{ET}_{\mathrm{c}}$ in an irrigated cotton field. The key objectives of this study were to (1) estimate daily $\mathrm{ET}_{\mathrm{c}}$ (or crop water use) and $\mathrm{ET}_{\mathrm{o}}$ experimentally, and (2) construct local straight line $K_{\mathrm{c}}$ curves for irrigated upland cotton. Comparison of local $K_{\mathrm{c}}$ values with FAO- $K_{\mathrm{c}}$ values and findings from other studies was also made.

\section{Materials and methods}

\subsection{Project location and study site characteristics}

The study site $\left(31^{\circ} 56^{\prime} \mathrm{N}\right.$ and $\left.91^{\circ} 14^{\prime} \mathrm{W}\right)$ is located at the Louisiana State University Agricultural Center, Northeast Research Station near St. Joseph, Tensas Parish, LA. It is approximately $1.5 \mathrm{~km}$ from the Mississippi River at an elevation of approximately $23 \mathrm{~m}$ above sea level. The climate of this region is considered humid according to the Thornthwaite classification system (Feddema, 2005); characterized by hot and humid summers and mild winters with the maximum and minimum air temperatures occurring in July and January, respectively, while maximum rainfall occurs in January and March. The study site is within the Upper Mississippi River Alluvial Plain ecoregion (east of the Ouachita River) and common soils include Sharkey clay, Tensas silty clay, Tensas-Sharkey complex, Tunica clay, and Commerce silt loam (LDEQ 2004, 2011). Agriculture is the primary land use of this region, with cotton, corn, and soybean production accounting for the majority of agricultural land use.

\subsection{Weighing lysimeters (installation and calibration)}

A description of the weighing lysimeters, including their location, soil, mechanical operation, drainage, and expected suitability for $\mathrm{ET}_{\mathrm{c}}$ measurement on Sharkey clay was provided by Clawson et al. (2009). The system consists of paired weighing lysimeters (with inner tanks of $1.5 \mathrm{~m}$ long, $1.5 \mathrm{~m}$ deep, and $1.0 \mathrm{~m}$ wide, resting on load cells within the outer tanks) centered $0.8 \mathrm{~m}$ apart on same cotton row. The four load cells of each lysimeter were connected to a Campbell Scientific data logger (CR 3000, Campbell Scientific, Inc., Logan, UT) for measuring changes in lysimeter weights. The same lysimeters used by Clawson et al. (2009) were used in the current study. The lysimeters were transferred to a new location approximately $200 \mathrm{~m}$ from the original site in 2008 . The field at the new site has a similar soil and soil water regime to the original site. In addition, it has advantages of increased uninterrupted fetch (at least $50 \mathrm{~m}$ in all direction) and a consistent near-level slope laser leveled for furrow irrigation. The soil inside the lysimeters was left intact from the original installation. The lysimeters were installed on a crop row approximately $1.0 \mathrm{~m}$ wide in the middle of 1 -ha field. The lysimeters were calibrated annually at the beginning of each growing season. Calibration was accomplished following the method of Howell et al. (1995) as described by Clawson et al. (2009). The offset and slope of the equation obtained by regressing lysimeter mass against the sum of the output from the four load cells were determined for each lysimeter using best fit regression equation. These were used in the data logger programming to convert raw outputs of load cells $\left(\mathrm{mVV}^{-1}\right)$ into equivalent masses $(\mathrm{kg})$ during the course of each growing season.

\subsection{Reference weather station}

Following the procedures set by the American Society of Civil Engineers (ASCE) for the estimation of $\mathrm{ET}_{0}$ from measured weather variables (Allen et al., 2005), all parameters needed for the computation of $\mathrm{ET}_{0}$ were obtained from a reference weather station located approximately $0.25 \mathrm{~km}$ from the experimental cotton field. The weather station is located in the middle of a 2-ha Bermuda grass (Cynodon dactylon L.) field, with a grass fetch of at least $50 \mathrm{~m}$ in all directions. A weather tower was instrumented with all sensors needed for the measurement of wind direction and speed (RM Young, 05103.5 wind monitor), air temperature, and relative humidity (Vaisala, HMP 45 AC), solar radiation (Li-COR, LI200SZ), and net all-wave radiation (Kipp and Zonen, NR lite), all recorded by a data logger (Campbell Scientific, CR 3000). All sensors and instruments were obtained from Campbell Scientific, Inc., Logan, UT. Instruments were calibrated and maintained following the recommendations provided by the manufacturers. The grass reference surface was treated annually with herbicides to reduce the infestation of broadleaf weeds. The field was mowed and flood irrigated periodically.

\subsection{Cotton establishment}

Lysimeters and the surrounding field were planted with cotton (Stoneville ST 5458 B2RF) on May 11 and May 10, respectively, for the 2010 and 2011 growing seasons. In both years, lysimeters and the immediate surrounding area (four rows on each side of the lysimeters) were hand planted with cotton seed and later thinned to match the field plant density of approximately 130,000 plants ha ${ }^{-1}$. The rest of the field was planted with a John Deere vacuum planter. In both growing seasons, cotton field was fertilized approximately 3 weeks after emergence with urea ammonium nitrate (UAN) at a rate of $136 \mathrm{~kg} \mathrm{Nha}^{-1}$. The immediate area surrounding the lysimeters was fertilized at the rate of $91 \mathrm{~kg} \mathrm{~N} \mathrm{ha}^{-1}$. In 2010, the lysimeters themselves were not fertilized due to a history of vigorous growth consistent with $\mathrm{N}$ accumulation. The cotton plants in the surrounding field (laser leveled) were irrigated by furrow method. In conjunction with furrow irrigation, the approximate accumulated $\mathrm{ET}_{\mathrm{c}}$ ( $\sim 801$ of water based on $5 \mathrm{~cm}$ water depth for each irrigation event) was replaced manually in each lysimeter using plastic buckets. Irrigation scheduling was accomplished with the aid of tensiometers installed at 30 and $60-\mathrm{cm}$ depths within the field and on the lysimeters. Irrigation was generally applied when soil water potential at $30 \mathrm{~cm}$ reached $-60 \mathrm{kPa}$ or less, especially within the lysimeters. Pest management was conducted as per Louisiana State University Agricultural Center (LSU AgCenter) recommendations, and all other management practices were typical of those used in northeast Louisiana cotton production. 


\subsection{Data collection and parameter computation}

Growing degree days (GDDs) and cotton phenological growth stages were recorded to allow $K_{\mathrm{c}}$ values to be associated with crop development. Growing degree days (GDDs) were calculated by assuming a base temperature of $15.6^{\circ} \mathrm{C}$ for cotton (Wright and Sprenkel, 2005), using the relationship presented below:

$\mathrm{GDD}=\left\{\frac{T_{\max }+T_{\min }}{2}\right\}-15.6$

where $T_{\max }$ is maximum air temperature and $T_{\min }$ is minimum air temperature $\left({ }^{\circ} \mathrm{C}\right)$ on a given day. The GDD variable is found to be useful in the inter-site and inter-seasonal transferability of cotton growth lengths and $K_{\mathrm{c}}$ values (Howell et al., 2004). Observations on cotton phenological growth stages which included seedlings, squaring, bloom, $25 \%$ boll open, and $50 \%$ boll open were recorded at approximately biweekly interval. Data reported ended at $85 \%$ open boll in 2010, when harvest aid application occurred, and 95\% open boll in 2011. At each observation, 10 representative cotton plants of healthy vigor were marked from 2-m sections of the surrounding field to identify the growth stages. If more than five plants within the selected section were observed to show any of the above referenced growth stages, the entire crop was assumed to have reached that particular growth stage. In both growing seasons, cotton plant height $(\mathrm{cm})$ was also recorded on the lysimeters as well as on east and westward side ( $\sim 30 \mathrm{~m}$ away) of the lysimeters as the distance from base of plant to the terminal node along with the phenological growth stages. Measurement of plant heights was made only during crop development and mid-season in each growing year. Cotton yield data were also recorded in each experimental year.

$\mathrm{ET}_{\mathrm{C}}$ was measured as changes in mass of the lysimeters, recorded using a CR 3000 data logger (Campbell Scientific, Inc., Logan, UT). Measurements were obtained at 1-s time intervals. The output from each load cell and the sum of the outputs from the four load cells of each lysimeter were recorded at intervals of 5 and $15 \mathrm{~min}$, representing the average of measurements recorded at 1 -s time intervals. Data acquired at 15-min intervals were used for estimating daily $\mathrm{ET}_{\mathrm{c}}$ as recommended by Howell et al. (1995), while the 5-min interval data were used in evaluating the quality of the data collected. Abnormal load cell outputs and fluctuations in output were scrutinized periodically. For a given time period, $\mathrm{ET}_{\mathrm{c}}$ was calculated as the difference in the mass of the lysimeter at the beginning and the end of the time period; thus, the positive difference of the lysimeter mass recorded at consecutive midnights was assumed to represent the cotton water use for the previous day. These differences expressed in $\mathrm{kg}$ were converted to a volume of water and then divided by the respective lysimeter evaporative areas of $1.551 \mathrm{~m}^{2}$ and $1.553 \mathrm{~m}^{2}$ for lysimeter 1 and 2 , respectively, to obtain the equivalent water depth in $\mathrm{mm}$. Data collected on days of rainfall, irrigation, drainage, and other activities that could interfere with the lysimeter functionality were not used. Days were also excluded when $\mathrm{ET}_{\mathrm{c}}$ data were available only from one lysimeter.

Reference evapotranspiration $\left(\mathrm{ET}_{0}\right)$ was calculated using the Standardized Reference Evapotranspiration Equation (SREE) developed by ASCE (Allen et al., 2005). Weather data needed for the computation of $\mathrm{ET}_{\mathrm{o}}$, which include solar radiation $\left(\mathrm{MJ} \mathrm{m} \mathrm{m}^{-2} \mathrm{~d}^{-1}\right)$, minimum, maximum, and dew point air temperatures $\left({ }^{\circ} \mathrm{C}\right)$, minimum and maximum relative humidity (\%) at 3-m height, and wind speed at 2-m height $\left(\mathrm{m} \mathrm{s}^{-1}\right)$ were recorded at hourly and daily intervals using a CR 3000 data logger (Campbell Scientific, Inc., Logan, UT) with time scan of $3 \mathrm{~s}$. Parameters measured at heights differing from those required for SREE inputs (temperatures and wind speed) were adjusted to the required height using the methods of Allen et al. (2005). Recommended quality control measures/procedures for meteorological data for the ASCE-SREE were followed as listed in Allen et al. (2005). Data collected on days of flood irrigation were not used.

A single-day crop coefficient $\left(K_{\mathrm{c}}\right)$ at any given stage was calculated as the ratio of $\mathrm{ET}_{\mathrm{c}}$ measured by lysimeters to $\mathrm{ET}_{\mathrm{o}}$ estimated by SREE of ASCE (Allen et al., 2005) for the same day. Each growing season was partitioned into four cotton growth stages: initial, development, midseason, and end season. The length of each growth stage was identified using general guidelines of FAO-56 paper on lengths of cotton developmental stages for Texas (Table 11 of Allen et al., 1998) modified by local observations on crop development in current study. For example, the length of initial growth stage of cotton is 30 days in Texas when planted in April (Table 11, Allen et al., 1998) and the length of this stage was expected to be 25 and 28 days for 2010 and 2011 in the current study (considering factors such as planting in May, short growing season, and relatively rapid transition in cotton phenology). The lengths of all other growth stages (development, midseason, and end season) were also adjusted accordingly in each growing season. Phenological stages observed in the field and for each observation date and the growth stage of cotton estimated by using FAO-56 paper during 2010 and 2011 growing season are presented in Table 1.

Moving averages of $K_{\mathrm{c}}$ values estimated during cotton growth stages (initial, mid, and end-season) were calculated and connected to develop straight line curves. Straight line curves were fitted by joining the last date of the line of the average initial stage $K_{\mathrm{c}}$ $\left(K_{\mathrm{c} \text {-ini }}\right)$ value to the first date of the line of the average midseason $K_{\mathrm{c}}\left(K_{\mathrm{c} \text {-mid }}\right)$ value, followed by joining the last date of the midseason line to the last day $K_{\mathrm{c}}$ value of the end season stage (end season $K_{\mathrm{c}}$ is designated as $\left.K_{\text {c-end }}\right)$. A similar approach was applied to the 2year straight line curve using the respective average $K_{\mathrm{c}}$ values and growth stage lengths. FAO $K_{\mathrm{c}}$ values adjusted to local conditions were also calculated using the values from Table 12 in FAO-56 and the equations given by FAO-56 (Allen et al., 1998), illustrated using the expressions for the initial stage as presented below:

$$
\begin{aligned}
K_{\mathrm{c}-\text { ini-FAO }}= & K_{\mathrm{c}-\text { ini }(\mathrm{Tab})} \\
& +\left[0.04\left(u_{2}-2\right)-0.004\left(\mathrm{RH}_{\min }-45\right)\right]\left(\frac{h}{3}\right)^{0.3}
\end{aligned}
$$

where $K_{\text {c-ini-FAo }}$ is the FAO-adjusted crop coefficient for the initial stage using local weather information, $K_{\mathrm{c} \text {-ini(Tab) }}$ is the tabulated crop coefficient for the initial stage obtained from Table 12 of FAO-56, $u_{2}$ is the mean daily wind speed adjusted to $2 \mathrm{~m}$ height during the initial season growth stage $\left(\mathrm{m} \mathrm{s}^{-1}\right), \mathrm{RH}_{\min }$ is the mean daily minimum relative humidity averaged over the initial season growth stage (\%), and $h$ is the mean plant height during the initial season stage $(\mathrm{m})$. Using irrigation frequency for fine textured soils from Fig. 30 of the FAO-56 bulletin (Allen et al., 1998) and reference $\mathrm{ET}_{0}$ data for initial growth stage, $K_{\mathrm{c} \text {-ini-FAo }}$ for each growing season was obtained graphically. An analogous approach was employed to calculate $K_{\mathrm{c}-\text { mid-FAO }}$ and $K_{\mathrm{c} \text {-end-FAO }}$ as described in FAO-56 (Allen et al., 1998).

\subsection{Conditions for measurements}

Appropriate environmental conditions are needed to ensure representative values of $\mathrm{ET}_{c}$ and $K_{\mathrm{c}}$ values (Allen et al., 1998, 2005). In the rows immediately surrounding the lysimeters, an additional application of UAN at the rate of $57 \mathrm{~kg} \mathrm{~N} \mathrm{ha}^{-1}$ was made to selected plants on 45 DAP in 2010 to counteract chlorotic symptoms and reduced growth. In spite of no $\mathrm{N}$ being applied within the lysimeters in the 2010 growing season, plants on both lysimeters exhibited more vigorous growth than those in the surrounding field. Although the causes are not known with certainty, the effect remained consistent with excessive $\mathrm{N}$ availability including a greater extent of dark green vegetation late in the season. In an effort to retard this 
Table 1

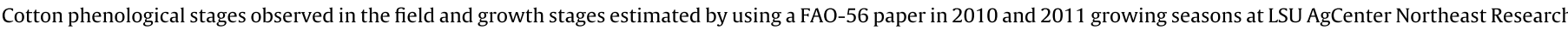
Station near St. Joseph, Louisiana, USA.

\begin{tabular}{|c|c|c|c|c|}
\hline \multirow[t]{2}{*}{ Cotton phenological stages ${ }^{b}$} & DAP $^{a}$ & Concurrent growth stages using FAO-56 & $\mathrm{DAP}^{\mathrm{a}}$ & Concurrent growth stages using FAO-56 \\
\hline & \multicolumn{2}{|r|}{2010} & \multicolumn{2}{|r|}{2011} \\
\hline Seedlings & 8 & Initial & 10 & Initial \\
\hline Squaring & 47 & Development & 45 & Development \\
\hline Bloom & 61 & Mid-season & 64 & Mid-season \\
\hline $25 \%$ open boll & 116 & End-season & 126 & End-season \\
\hline $50 \%$ open boll & 129 & - & 140 & - \\
\hline $85 \%$ open boll & 152 & - & - & - \\
\hline $95 \%$ open boll & - & - & 162 & - \\
\hline
\end{tabular}

a DAP, days after planting; FAO, Food and Agricultural Organization.

b Phenological growth stages were observed at approximately biweekly interval. $85 \%$ open boll was end data point in 2010 when defoliant was applied; whereas $95 \%$ open boll was end data point in 2011. No defoliant was used in 2011

c The entire cotton growing season was divided into four major growth stages as described in FAO-56 paper (Allen et al., 1998). The duration of these stages is shown in Table 3.

excessive growth and maximize the uniformity of the lysimeter crop canopy with the surrounding field, selective trimming of older leaves and branches of lysimeter plants was conducted on June 25 , 2010 (46 DAP) and irrigation was withheld from the lysimeters starting June 19 to July 1 (40-51 DAP). Trimming was targeted to older leaves only and the apical meristem was left intact. The process reduced the total leaf area to a level that appeared similar to that of the surrounding crop and retarded the vigorous growth, enabling the plants in the surrounding field to catch up with and become approximately equal to the lysimeter plants (in respect to the growth characteristics such as plant height, primary branches, tissue greenness, leaf area, flowering, and boll set). However, the cotton canopy on the lysimeter rows thereafter remained somewhat wider than the width of the average cotton canopy in the surrounding rows. No attempt was made to adjust reported $\mathrm{ET}_{\mathrm{c}}$ values for discrepancies in canopy height or width. The potential impact of these discrepancies could be increased $\mathrm{ET}_{\mathrm{c}}$. Cotton water use $\left(\mathrm{ET}_{\mathrm{c}}\right)$ and $K_{\mathrm{c}}$ values from June 19 to July 1 (40-51 DAP) were not reported. To avoid similar difficulties in 2011, the nitrogen fertilizer rate on the lysimeters was limited to $45 \mathrm{~kg} \mathrm{~N} \mathrm{ha}^{-1}$. Cotton canopy was uniform on both lysimeters as well as surrounding areas in 2011.

Conditions at the reference weather station were generally conducive for reliable estimates of $\mathrm{ET}_{0}$ in both growing seasons. However, during drought periods in 2010, irrigation frequency may have been insufficient to avoid water stress to the grass surrounding the weather station. $K_{\mathrm{c}}$ computation from June 19 to July 1 (40-51 DAP) was not included, which avoided reporting data from the most extreme period of drought stress on the weather station in 2010. In each year, the weather station grass was mowed at intervals of approximately 3 weeks, insufficient to maintain the grass below $12 \mathrm{~cm}$ (Allen et al., 2005) but still sufficiently frequent to retard excessive growth and maintain a uniform grass surface.

\section{Results and discussion}

\subsection{Weather characteristics and climatic conditions}

Weather variables including air temperature, relative humidity $(\mathrm{RH})$, wind speed $\left(u_{2}\right)$, solar radiation, vapor pressure deficit (VPD), rainfall, and $\mathrm{ET}_{\mathrm{o}}$ for 2010 and 2011 study periods are summarized in Table 2. With the exception of some differences in rainfall distribution, local conditions were somewhat similar in both growing seasons. For example, mean air temperature was $24.8^{\circ} \mathrm{C}$ in 2010 and $24.7^{\circ} \mathrm{C}$ in 2011 growing seasons. Mean values of solar radiation, wind speed, and VPD were also similar in both growing seasons (Table 2). Total accumulated rainfall amounts of $351.8 \mathrm{~mm}$ (2010)
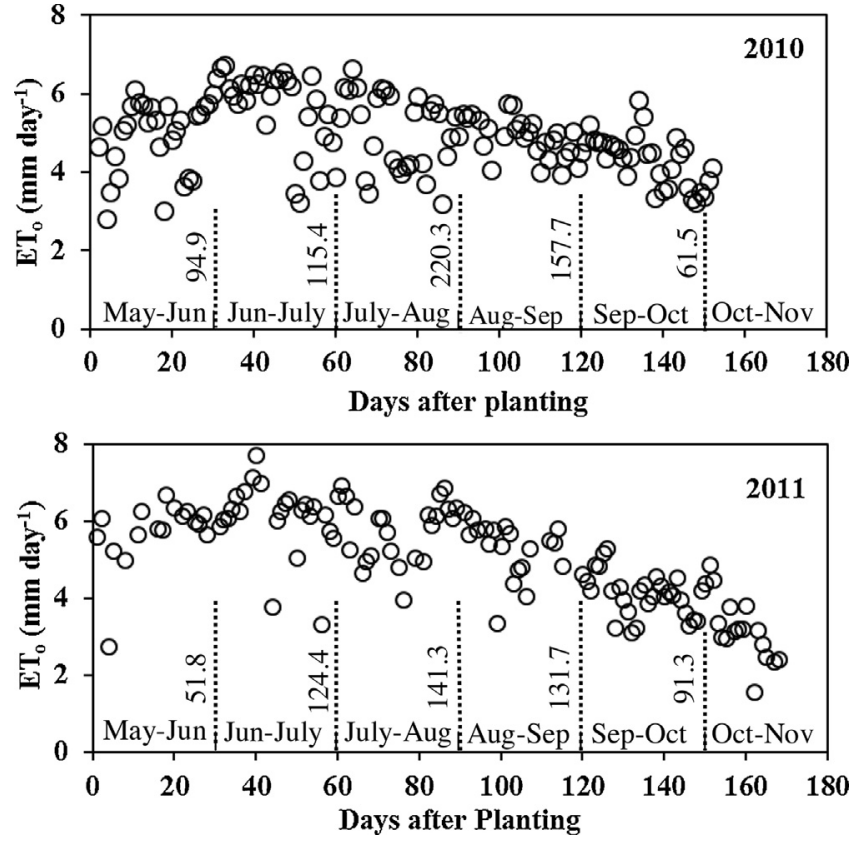

Fig. 1. Estimated daily reference evapotranspiration $\left(E_{0}\right)$ at the study site located near St. Joseph, Louisiana, USA, for 2010 and 2011 cotton growing seasons. Cotton was planted May 11 in 2010 and May 10 in 2011. Numerical values along the vertical dashed lines represent accumulated amount of water $(\mathrm{mm})$ supplied to weather station grass surface through irrigation and rainfall during that particular time of the year.

and $371.9 \mathrm{~mm}$ (2011) were recorded. More rainfall events (data not shown) and greater rainfall amounts were recorded in August $(156.7 \mathrm{~mm})$ in 2010 , while June $(104.1 \mathrm{~mm})$, July $(105.7 \mathrm{~mm})$, and September ( $103.1 \mathrm{~mm}$ ) received more rainfall in 2011 (Table 2).

Daily $\mathrm{ET}_{\mathrm{o}}$ ranged from 3.32 to $6.68 \mathrm{~mm} \mathrm{~d}^{-1}$ in 2010 and from 1.56 to $7.71 \mathrm{~mm} \mathrm{~d}^{-1}$ in 2011 (Fig. 1). In both seasons, $\mathrm{ET}_{\mathrm{o}}$ followed a somewhat similar pattern throughout the growing periods. Maximum $\mathrm{ET}_{0}$ was observed in June at approximately 32 days after planting (DAP) of cotton in 2010 and 40 DAP of cotton in 2011, while minimum $\mathrm{ET}_{\mathrm{o}}$ was observed late in the season. Similar $\mathrm{ET}_{\mathrm{o}}$ patterns in both growing seasons could possibly be attributed to similar environmental conditions as previously discussed. Mean monthly $\mathrm{ET}_{\mathrm{o}}$ values of $4.7 \mathrm{~mm}$ and $5.0 \mathrm{~mm}$ were observed in the 2010 and 2011 cotton growing seasons, respectively (Table 2). Based on the $\mathrm{ET}_{\mathrm{o}}$ values, it is apparent that this region falls within the humid climate according to FAO-56 (Allen et al., 1998), as would be expected given the Thornthwaite classification noted earlier. 
Table 2

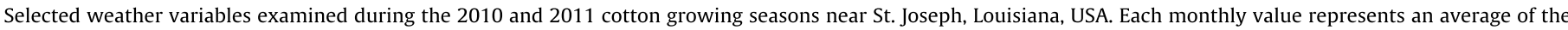
daily values. Each monthly rainfall value is the total rainfall amount recorded for the month. ${ }^{a}$

\begin{tabular}{|c|c|c|c|c|c|c|c|c|}
\hline \multirow[t]{2}{*}{ Parameter } & \multicolumn{6}{|c|}{ Month } & \multirow[t]{2}{*}{ Average } & \multirow[t]{2}{*}{ Total } \\
\hline & May & June & July & August & September & October & & \\
\hline \multicolumn{9}{|l|}{2010} \\
\hline Air temp $\left({ }^{\circ} \mathrm{C}\right)$ & 23.1 & 27.8 & 27.5 & 28.0 & 24.4 & 18.1 & 24.8 & - \\
\hline $\mathrm{RH}(\%)$ & 63.7 & 62.6 & 64.9 & 66.8 & 59.0 & 54.4 & 61.9 & - \\
\hline Solar radiation $\left(\mathrm{MJ} \mathrm{m}^{-2} \mathrm{~d}^{-1}\right)$ & 22.7 & 24.2 & 21.6 & 20.3 & 21.8 & 18.1 & 21.5 & - \\
\hline$u_{2}\left(\mathrm{~ms}^{-1}\right)$ & 1.7 & 1.7 & 1.4 & 1.4 & 1.2 & 1.6 & 1.5 & - \\
\hline $\mathrm{VPD}(\mathrm{kPa})$ & 1.3 & 1.6 & 1.4 & 1.3 & 1.5 & 1.4 & 1.4 & - \\
\hline $\mathrm{ET}_{\mathrm{o}}(\mathrm{mm})$ & 5.0 & 5.7 & 5.0 & 4.7 & 4.5 & 3.5 & 4.7 & - \\
\hline Rainfall (mm) & 34.8 & 22.6 & 76.2 & 156.7 & 25.4 & 36.1 & 58.6 & 351.8 \\
\hline \multicolumn{9}{|l|}{2011} \\
\hline Air temp $\left({ }^{\circ} \mathrm{C}\right)$ & 22.4 & 27.8 & 28.0 & 29.0 & 23.5 & 17.4 & 24.7 & - \\
\hline $\mathrm{RH}(\%)$ & 68.4 & 70.8 & 75.5 & 67.9 & 70.6 & 65.6 & 69.8 & - \\
\hline Solar radiation $\left(\mathrm{MJ} \mathrm{m}^{-2} \mathrm{~d}^{-1}\right)$ & 25.2 & 25.7 & 23.0 & 23.6 & 19.3 & 17.6 & 22.4 & - \\
\hline$u_{2}\left(\mathrm{~ms}^{-1}\right)$ & 2.2 & 1.7 & 1.3 & 1.4 & 1.8 & 1.5 & 1.6 & - \\
\hline $\mathrm{VPD}(\mathrm{kPa})$ & 1.2 & 1.4 & 1.4 & 1.8 & 1.2 & 1.2 & 1.4 & - \\
\hline $\mathrm{ET}_{\mathrm{o}}(\mathrm{mm})$ & 5.6 & 5.9 & 5.3 & 5.6 & 4.1 & 3.7 & 5.0 & - \\
\hline Rainfall (mm) & 21.3 & 104.1 & 105.7 & 29.2 & 103.1 & 8.4 & 62.0 & 371.9 \\
\hline
\end{tabular}

${ }^{\text {a }} \mathrm{RH}$, relative humidity; $u_{2}$, wind speed at 2-m height; VPD, vapor pressure deficit; $\mathrm{ET}_{0}$, reference evapotranspiration.
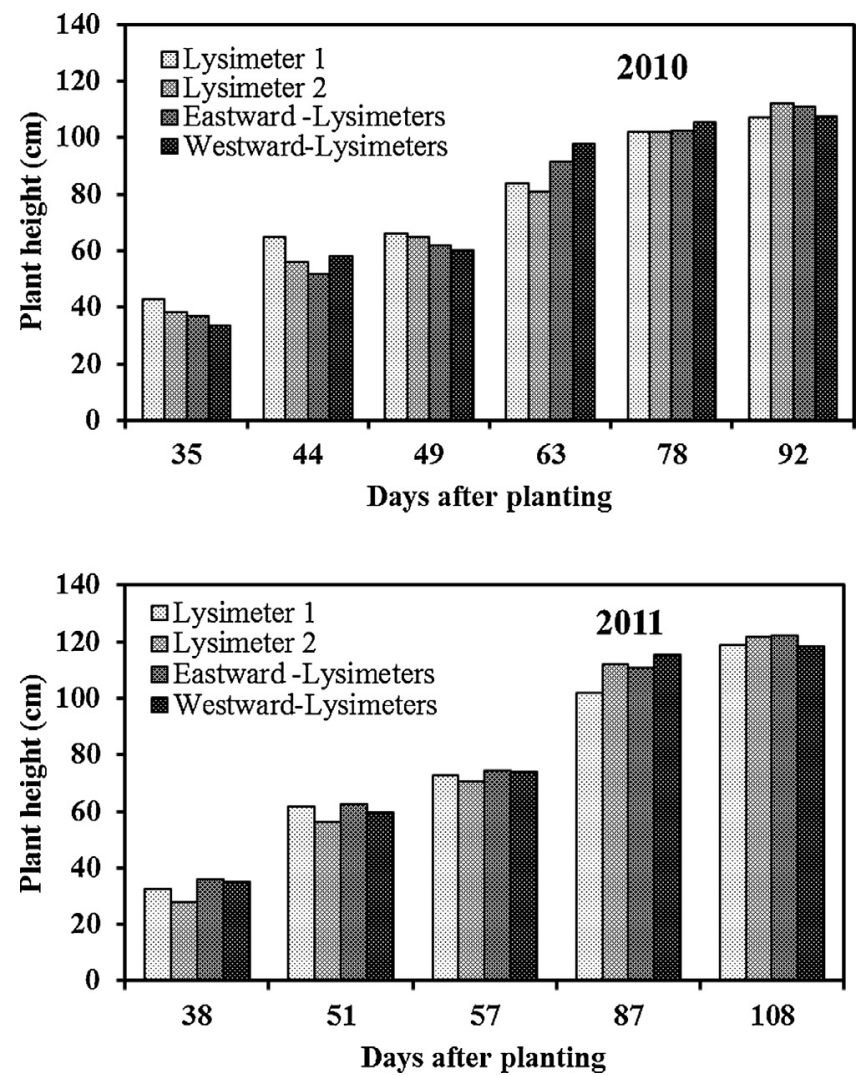

Fig. 2. Average cotton plant heights observed on the paired weighing lysimeters along with east and westward side of the lysimeters during 2010 and 2011 growing seasons near St. Joseph, Louisiana, USA. Both eastward and westward sites were approximately $30 \mathrm{~m}$ away from the paired lysimeters.

\subsection{Cotton growth characteristics}

The slight differences in average plant height (Fig. 2) between the two lysimeters as well as between the lysimeters and other field representative sites ( $\sim 30$ m away on east and westward sides of the lysimeters) are not unusual given the heterogeneity in plant height observed in a typical cotton field in the local environment. Variation in cotton plant heights within a variety is often attributed to environmental conditions and management practices (Siebert
Table 3

Cotton growth stages (following FAO-56 paper), corresponding lengths, and cumulative growing degree days observed during 2010 and 2011 cotton growing seasons near St. Joseph, Louisiana, USA. ${ }^{a}$

\begin{tabular}{lccccr}
\hline Stage & Initial & Development & Mid-season & End-season & Total \\
\hline $\mathbf{2 0 1 0}$ & & & & & \\
Length (days) & 25 & 36 & 50 & 41 & 152 \\
CGDD $\left({ }^{\circ} \mathrm{C}\right)$ & 189 & 441 & 606 & 300 & 1536 \\
$\mathbf{2 0 1 1}$ & & & & 48 & \\
Length (days) & 28 & 40 & 52 & 215 & 168 \\
CGDD $\left({ }^{\circ} \mathrm{C}\right)$ & 242 & 518 & 668 & & \\
\hline
\end{tabular}

et al., 2006). In the current study, increase in plant height occurred more slowly after 78 DAP in 2010 and 87 DAP in 2011. This is typical of cotton and reflects the increasing resource demand of bolls during vegetative growth.

Total cumulative GDD values of $1536^{\circ} \mathrm{C}$ in 2010 and $1643{ }^{\circ} \mathrm{C}$ in 2011 were observed between planting and $85 \%$ open bolls in 2010 and 95\% in 2011 (Table 3). The average total cumulative GDD of $1590^{\circ} \mathrm{C}$ for both growing seasons observed at this study site is comparable to other cotton-producing regions such as the semiarid lands of Brazil, Syria, and Texas, USA (Farahani et al., 2008; Ko et al., 2009; Bezerra et al., 2012). Average cotton lint yield was approximately $1480 \mathrm{~kg} \mathrm{ha}^{-1}$.

\subsection{Crop water use $\left(E T_{c}\right)$ and crop coefficients $\left(\mathrm{K}_{c}\right)$}

Single day cotton $\mathrm{ET}_{\mathrm{c}}$ estimations for 2010 and 2011 are shown in Fig. 3. The temporal pattern of $\mathrm{ET}_{\mathrm{C}}$ for each cotton growing season observed at the study site was comparable to the trend described in FAO-56 (Allen et al., 1998). This trend generally shows a gradual increase in $\mathrm{ET}_{\mathrm{c}}$ from the initial stage, peaking at the midseason (approximately 60-105 DAP) and steadily declining toward the end of the season. Average daily cotton $\mathrm{ET}_{\mathrm{c}}$ values (during mid-season) were approximately $7.1 \mathrm{~mm} \mathrm{~d}^{-1}$ in 2010 and $5.9 \mathrm{~mm} \mathrm{~d}^{-1}$ in 2011. Compared to existing literature, midseason $\mathrm{ET}_{\mathrm{c}}$ values observed in this study are lower than those observed in Texas (Howell et al., 2004; Ko et al., 2009). However, these $\mathrm{ET}_{\mathrm{C}}$ values are comparable to Brazilian semi-arid lands like Apodi and southern part of the Ceará state (Bezerra et al., 2010, 2012).

Estimated daily $K_{\mathrm{c}}$ values expressed as a function of DAP for the 2010 and 2011 cotton growing seasons are shown in Fig. 4. Similar to $\mathrm{ET}_{\mathrm{c}}$, the observed $K_{\mathrm{c}}$ trend in each growing season is 

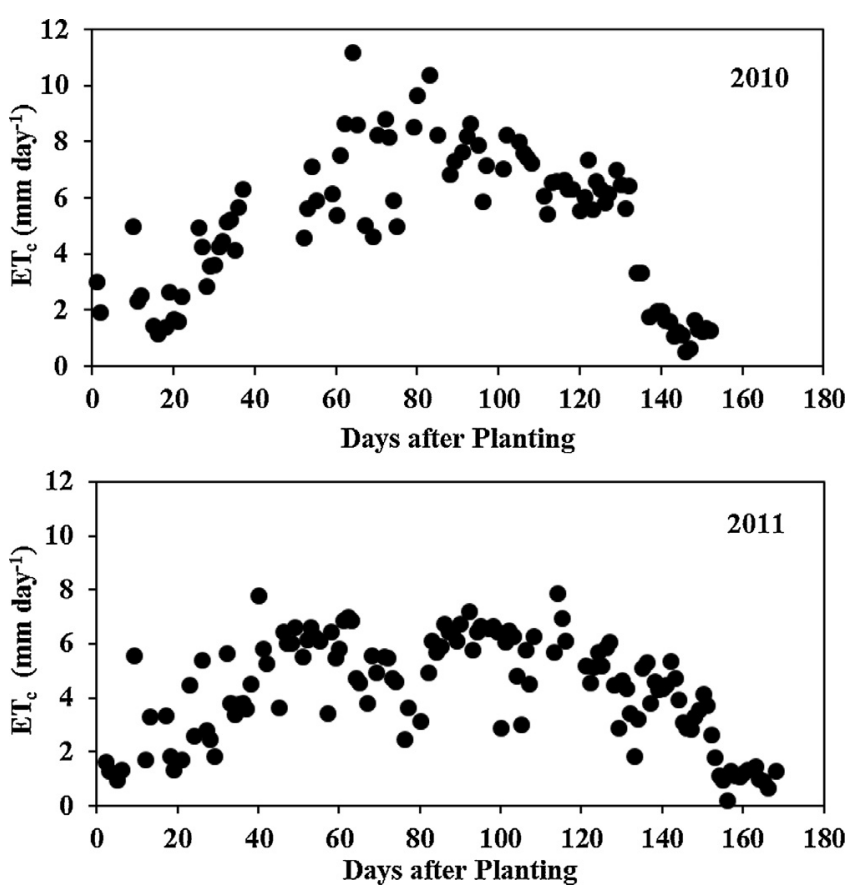

Fig. 3. Daily crop evapotranspiration $\left(\mathrm{ET}_{\mathrm{c}}\right.$ ) for 2010 and 2011 cotton growing seasons near St. Joseph, Louisiana, USA. Each data point represents the average value of two weighing lysimeters.

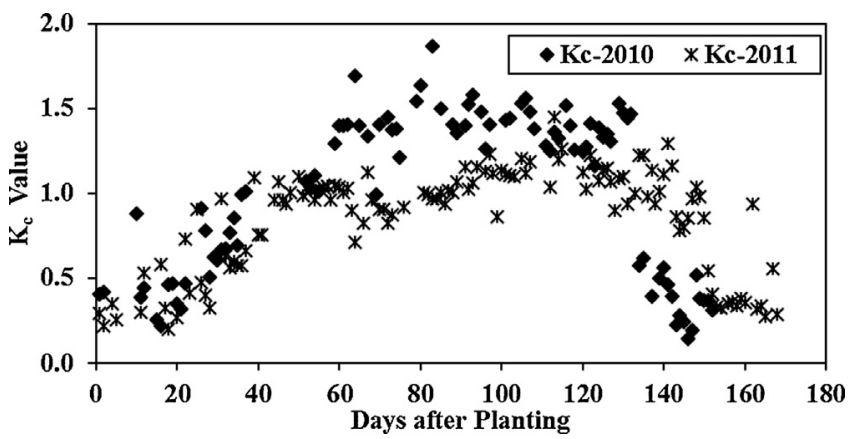

Fig. 4. Daily crop coefficients $\left(K_{c}\right)$ for 2010 and 2011 cotton growing seasons near St. Joseph, Louisiana, USA. Each data point represents the average value of two weighing lysimeters.

comparable to the trends described in FAO-56 (Allen et al., 1998). The trend shows a gradual increase in $K_{\mathrm{c}}$ from the initial stage, peaking at the midseason (approximately 60-105 DAP), and steadily declining toward the end of the season. Average daily $K_{\mathrm{c}}$ values (during mid-season) were approximately 1.44 in 2010 and 1.06 in 2011. It is evident that there were more rainfall events in the month of August (mid-season stage) in 2010 compared to 2011 growing season (Table 2). The more wetting events during this period might have influenced the cotton water use, resulting in higher $K_{\mathrm{c}}$ values in 2010 compared to 2011. Therefore, variation in results could partly be attributed to seasonal variation in rainfall frequency during peak growth period of cotton observed in 2010 compared to 2011 growing season.

\subsection{Stage-specific $\mathrm{K}_{c}$ : comparison to FAO-adjusted and other published studies}

Locally developed and FAO-adjusted $K_{\mathrm{c}}$ values for initial, midseason, and end season stages of upland irrigated cotton for northeastern Louisiana are presented in Table 4 and Fig. 5. Cotton phenological growth stages such as seedling, squaring, bloom, and
Table 4

Locally developed $K_{\mathrm{c}}$ and FAO-adjusted $K_{\mathrm{c}}$ values for 2010 and 2011 for upland irrigated cotton near St. Joseph, Louisiana, USA. ${ }^{a}$

\begin{tabular}{llll}
\hline Locally developed $K_{\mathrm{c}}$ & & \\
\hline & $K_{\text {c-ini-Local }}$ & $K_{\text {c-mid-Local }}$ & $K_{\text {c-end-Local }}$ \\
\hline 2010 & 0.42 & 1.44 & 0.62 \\
2011 & 0.42 & 1.06 & 0.78 \\
Average & 0.42 & 1.25 & 0.70
\end{tabular}

FAO-adjusted $K_{\mathrm{c}}$

\begin{tabular}{llll}
\hline & $K_{\text {c-ini-FAO }}$ & $K_{\text {c-mid-FAO }}$ & $K_{\text {c-end-FAO }}$ \\
\hline 2010 & 0.55 & 1.18 & 0.64 \\
2011 & 0.58 & 1.18 & 0.62 \\
Average & 0.57 & 1.18 & 0.63 \\
\hline
\end{tabular}

a $K_{\mathrm{c}}$, crop coefficient; FAO, Food and Agricultural Organization; Number of days used for $K_{\mathrm{c}}$ estimation in 2010: $K_{\text {c-ini-Local }}=13, K_{\text {c-mid-Local }}=35, K_{\text {c-end-Local }}=29$; number of days used for $K_{\mathrm{c}}$ estimation in 2011: $K_{\mathrm{c} \text {-ini-Local }}=15 ; K_{\mathrm{c} \text {-mid-Local }}=33$; $K_{\text {c-end-Local }}=37$.
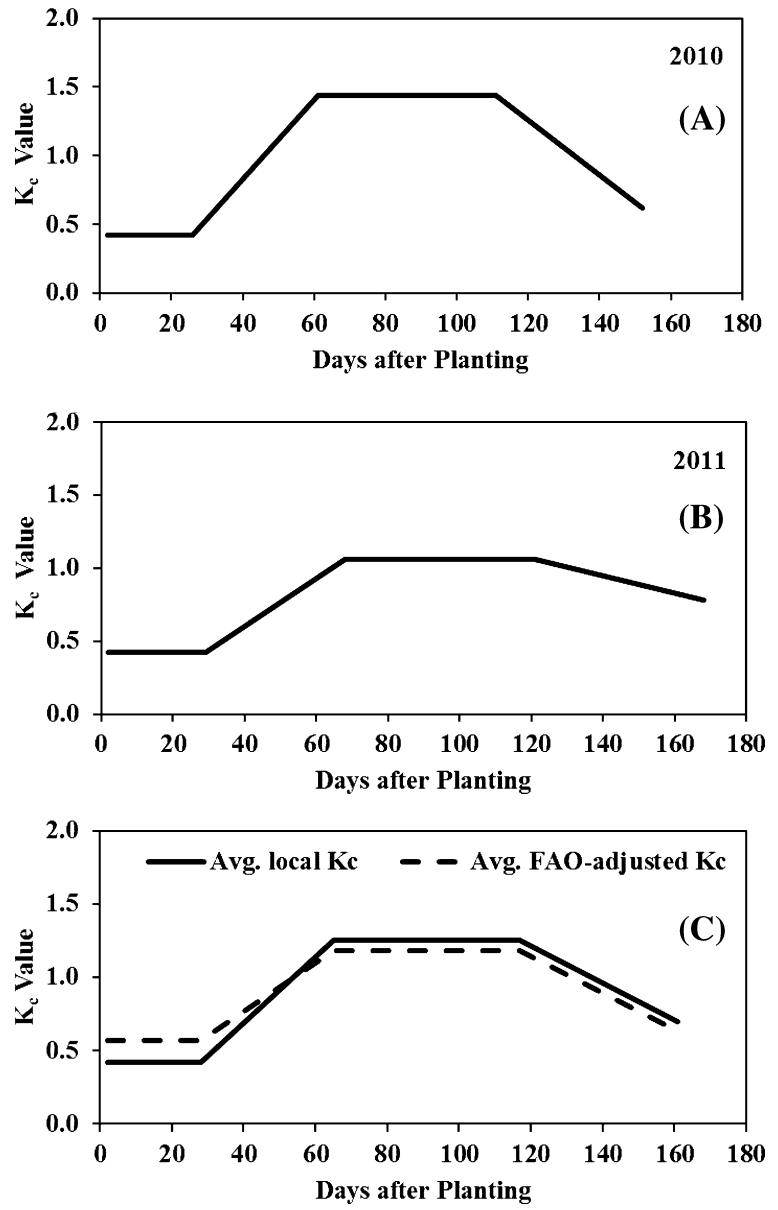

Fig. 5. Straight line curves of locally developed crop coefficient $\left(K_{\mathrm{c}}\right)$ for (A) 2010 growing season and (B) 2011 growing season. (C) Average of 2010 and 2011 local $K_{C}$ compared to the FAO-adjusted $K_{\mathrm{c}}$ values.

$25 \%$ open boll were observed during initial, developmental, mid, and end-season growth stages, respectively, in each growing season (Table 1), following FAO-56 recommendations. Therefore, locally developed $K_{\mathrm{c}}$ values presented in Table 4 can be transferred to corresponding phenological growth stages of cotton for this region. For example, locally developed $K_{\mathrm{c}}$ value of 0.42 in this study can be utilized for scheduling irrigation at seedling stage of cotton. Similar approach can be adopted for other phenological stages such as 
bloom and $25 \%$ open boll stage of cotton, with little approximations and careful field observations.

Locally estimated $K_{\mathrm{c}}$ values differed from FAO-adjusted $K_{\mathrm{c}}$ values for these cotton growth stages by $6-26 \%$. The average $K_{\mathrm{c}}$ values from the 2-year study indicated that $K_{\mathrm{c} \text {-ini-local }}$ value was lower than $K_{\text {c-ini-FAo }}$ value by approximately $26 \%$. The 2 -year average $K_{\text {c-ini-local }}$ value of 0.42 observed at the study site was quite similar to those observed in India (Mohan and Arumugam, 1994), Brazilian semiarid regions (Azevedo et al., 1993) and Texas (Ko et al., 2009). However, average $K_{\mathrm{c} \text {-ini-local }}$ observed in this study is $45 \%$ higher than that observed in Syria (Farahani et al., 2008) and 44\% lower than that observed in semi-arid lands of Brazil (Bezerra et al., 2012).

The average $K_{\mathrm{c} \text {-mid-local }}$ value of 1.25 from this study was greater than $K_{\text {c-mid-FAo }}$ by $6 \%$ only. This average $K_{\text {c-mid-local }}$ value is quite comparable to those found in semi-arid lands of Brazil (Bezerra et al., 2012), Texas (Ko et al., 2009), and Arizona (Hunsaker, 1999). However, the value of $K_{\mathrm{c} \text {-mid-local }}$ found in this study differed from other cotton-producing regions including the northern High Plains of Texas (Howell et al., 2004), California (Grismer, 2002), northern Syria (Farahani et al., 2008), and India (Mohan and Arumugam, 1994), by a difference of $4-19 \%$.

The average $K_{\mathrm{c} \text {-end-local }}$ value $(0.70)$ from the 2 years of this study exceeded that of $K_{\text {c-end-FAo }}$ by $11 \%$. The average $K_{\text {c-end-local }}$ value observed in this study is lower than those reported by Ko et al. (2009) in Uvalde, Texas, USA; Grismer (2002) in the Sacramento and San Joaquin valleys and desert counties of California, USA; and Bezerra et al. (2012) in the semi-arid lands of Brazil, by a difference ranging from $10 \%$ to $25 \%$. However, $K_{\text {c-end-local }}$ value of 0.70 exceeded by $6-79 \%$ those found in other cotton-producing regions including India (Mohan and Arumugam, 1994), Brazilian semi-arid region (Azevedo et al., 1993), Syria (Farahani et al., 2008) and northern Texas High Plains, USA (Howell et al., 2004).

The differences in locally developed $K_{c}$ values from the study site and other sites can be attributed to differences in management practices, cultivars, growing window, and local weather conditions. $K_{\mathrm{c}}$ methodology has been found to be very sensitive to irrigation management, especially during the initial and later stages of crop development (Allen et al., 1998; Farahani et al., 2008; Bezerra et al., 2012). This sensitivity of $K_{\mathrm{c}}$ values primarily depends on the intensity and frequency of soil wetness due to irrigation or rainfall (Allen et al., 1998). In addition, other agronomic practices for cotton including date of planting, pest and nutrient management and irrigation methodology also influence $K_{\mathrm{c}}$ values (Allen et al., 1998). The results generally support the suitability of FAO-recommended $K_{c}$ values for mid-season and end of season growth stages in the mid-south U.S. However, the observed differences in locally developed and FAO-adjusted $K_{\mathrm{c}}$ values during initial growth stages, as well as the differences between the findings from this study and previous studies, further support the need for the development and use of locally developed $K_{\mathrm{c}}$ for irrigation scheduling in cotton.

\section{Conclusions}

The results of this study lay the groundwork for improvements in irrigation practices in northeast Louisiana and the Mississippi Delta. The $\mathrm{ET}_{\mathrm{c}}$ values obtained from this study provide a knowledge base of cotton water use under local environmental conditions that will have value for irrigation and research purposes. $K_{\mathrm{c} \text {-ini-local }}$ was 0.42 in both years, $K_{\mathrm{c} \text {-mid-local }}$ ranged from 1.06 in 2011 to 1.44 in 2010 , and $K_{\text {c-end-local }}$ ranged from 0.62 in 2010 to 0.78 in 2011 . These values provide a basis for the development of $K_{\mathrm{c}}$-based irrigation scheduling in the region.

\section{Acknowledgments}

We acknowledge the support of Cotton Incorporated and the faculty and staff of the Northeast Research Station, Louisiana State University AgCenter for their assistance. We also thank Sean Hribal and Yin-Lin (Jack) Chiu for assisting with data logger programs.

\section{References}

Allen, R.G., Pereira, L.S., Raes, D., Smith, M., 1998. Crop evapotranspiration: guidelines for computing crop water requirements. In: United Nations FAO, Irrigation and Drainage Paper 56. FAO, Rome, Italy

Allen, R.G., Walter, I.A., Elliott, R.L., Howell, T.A., Itenfisu, D., Jensen, M.E., Snyder, R.L. (Eds.), 2005. The ASCE Standardized Reference Evapotranspiration Equation. Am. Soc. Civil Eng., Reston, VA, 59 pp.

Allen, R.G., Pereira, L.S., 2009. Estimating crop coefficients from fraction of ground cover and height. Irrig. Sci. 28, 17-34.

Azevedo, P.V., Rao, T.V.R., Amorim Neto, M.S., Bezerra, J.R.C., Espínola Sobrinho, J., Maciel, G.F., 1993. Necessidades hídricas da cultural do algodoeiro. Pesq Agropecu. Bras. 28 (1), 863-870 (in Portuguese with English abstract).

Bezerra, J.R.C., Azevedo, P.V., Silva, B.B., Dias, J.M., 2010. Evapotranspiração e coeficiente de cultivo do algodoeiro BRS-200 Marrom. Irrig. Rev. Bras. Eng. Agric Ambient. 14 (6), 625-632 (in Portuguese with English abstract)

Bezerra, B.G., da Saliva, B.B., Bezerra, J.R.C., Sofiatti, V., dos Santos, C.A.C., 2012. Evapotranspiration and crop coefficient for sprinkler-irrigated cotton crop in Apodi Plateau semiarid lands of Brazil. Agric. Water Manag. 107, 86-93.

Clawson, E.L., Hribal, S.A., Piccinni, G., Hutchinson, R.L., Rohli, R.V., Thomas, D.L., 2009. Weighing lysimeters for evapotranspiration research on clay soil. Agron. J. 101, 836-840.

Doorenbos, J., Pruitt, W.O., 1977. Guidelines for Predicting Crop Water Requirements. Irrig. and Drain. Paper No. 24, 2nd ed. Food Agric. Org. United Nations, Rome, Italy, $144 \mathrm{pp}$.

Farahani, H.J., Oweis, T.Y., Izzi, G., 2008. Crop coefficient for drip-irrigated cotton in a Mediterranean environment. Irrig. Sci. 26, 275-383.

Feddema, J.J., 2005. A revised Thornthwaite-type global climate classification. Phys. Geogr. 26 (6), 442-466.

Grismer, M.E., 2002. Regional cotton lint yield, ETc, and water value in Arizona and California. Agric. Water Manag. 54 (3), 227-242.

Howell, T.A., Schneider, A.D., Dusek, D.A., Marek, T.H., Steiner, J.L., 1995. Calibration and scale performance of Bushland weighing lysimeters. Trans. ASAE 38 (4), 1019-1024.

Howell, T.A., Evett, S.R., Tolk, J.A., Schneider, A.D., 2004. Evapotranspiration of fulldeficit-irrigated, and dryland cotton on the Northern Texas High Plains. J. Irrig. Drain. Eng. 130 (4), 277-285.

Hunsaker, D.J., 1999. Basal crop coefficients and water for early maturity cotton. Trans. ASAE 42 (4), 927-936.

Hunsaker, D.J., Pinter Jr., P.J., Barnes, E.M., Kimball, B.A., 2003. Estimating cotton evapotranspiration crop coefficients with a multispectral vegetation index. Irrig. Sci. 22, 95-104.

Jensen, M.E., 1968. Water consumption by agricultural plants. In: Kozlowski, T.T. (Ed.), Water Deficits and Plant Growth, vol. II. Academic Press, Inc., New York, pp. $1-22$.

Ko, J., Piccinni, G., Marek, T., Howell, T., 2009. Determination of growth-stage specific crop coefficients $\left(K_{\mathrm{c}}\right)$ of cotton and wheat. Agric. Water Manag. 96 (12), 1691-1697

LDEQ 2004. Lake St. Joseph watershed implementation plan, Available at: http://nonpoint.deq. louisiana.gov/wqa/links/watershedplan/ouachita/Lake_ St_Joseph_Final.pdf (accessed 7.05.14).

LDEQ 2011. Tensas River watershed implementation plan, Available at: http:// nonpoint.deq.louisiana.gov/docs/000001_Annual_Report_2011_1.pdf (accessed on 6.05.14).

Mohan, S., Arumugam, N., 1994. Crop coefficient of major crops in south India. Agric Water Manag. 26 (1-2), 67-80

Siebert, J.D., Stewar, A.M., Leonard, B.R., 2006. Comparative growth and yield of cotton planted at various densities and configurations. Agron. J. 98 (3), $562-568$.

United States Department of Agriculture National Agricultural Statistics Service (USDA-NASS), 2013. Crop Production, http://www.usda.gov/nass/PUBS/ TODAYRPT/crop1113.pdf

Vories, E.D., Hogan, R., Tacker, P.L., Glover, R.E., Lancaster, S.W., 2007. Estimating the impact of delaying irrigation for midsouth cotton on clay soil. Trans. ASABE 50 (3), 929-937.

Wright, D.L., Sprenkel, R.K., 2005. Cotton growth and development. Agronomy Department, Florida Cooperative Extension Service, Institute of Food and Agricultural Sciences, University of Florida, Available at: http://edis.ifas.ufl.edu/ ag235 (accessed 10.10.12) 